\title{
Maternal adaptations of pancreatic islets and glucose metabolism after lactation
}

\author{
Gustavo Canul-Medina1', Leticia Riverón-Negrete¹, Karina Pastén-Hidalgo², Paulina Morales-Castillo1, \\ Francisco García-Vázquez ${ }^{3}$ and Cristina Fernandez-Mejia1
}

1Unidad de Genética de la Nutrición, Instituto de Investigaciones Biomédicas, Universidad Nacional Autónoma de México/Instituto Nacional de Pediatría, Mexico City, Mexico

${ }^{2}$ Cátedra CONACYT, Instituto Nacional de Pediatría, Mexico City, Mexico

${ }^{3}$ Laboratorio de Immunología y Alergia, Departamento de Análisis Clínicos y Estudios Especiales, Instituto Nacional de Pediatría, Mexico City, Mexico

Correspondence should be addressed to C Fernandez-Mejia: crisfern@biomedicas.unam.mx

\begin{abstract}
Pancreatic islets adapt to metabolic requirements and the hormonal milieu by modifying their size and hormone secretions. Maternal glucose demands and hormonal changes occur after weaning, to rapidly re-establish bone mineralization. Minimal information exists about glucose metabolism and pancreatic islets after lactation. This study investigated islet morphology and glucose homeostasis for 14 days after lactation in C57BL/6NHHsd mice. Compared to the day of weaning, rapid increases in the islets' area and number of beta cells were found from the first day post-lactation, attaining maximum values on the third day post-weaning. These changes were accompanied by modifications in glucose-induced insulin secretion, glucose tolerance and insulin sensitivity. Islet-cell proliferation was already augmented before lactation ceased. Serum undercarboxylated osteocalcin concentrations increased significantly post-lactation; however, it is unlikely that this enhancement participates in earlier cell proliferation augmentation or in decreasing insulin sensitivity. Islet serotonin content was barely expressed, and serum calcium concentrations decreased. By the 14th day post-weaning, islets' area and glucose homeostasis returned to age-matched virgin mice levels. These findings recognize for the first time that increases in islet area and insulin secretion occur during physiological post-weaning conditions. These results open up new opportunities to identify molecules and mechanisms participating in these processes, which will help in developing strategies to combat diabetes.
\end{abstract}

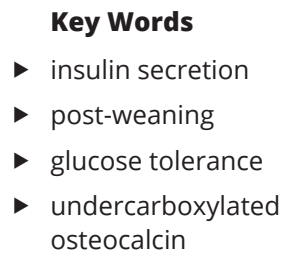

Journal of Endocrinology (2021) 248, 1-15

\section{Introduction}

Female physiology is modified during pregnancy and lactation to meet the nutritional demands of the fetus and the neonate. The increased glucose requirements of the developing infant require major adjustments in glucose homeostasis (Williamson 1980, Bell \& Bauman 1997) and involve morphological, hormonal and metabolic changes in different tissues, which are managed by diverse signals (Neville et al. 2002, Kovacs 2016, Canul-
Medina \& Fernandez-Mejia 2019). After weaning, a new hormonal and metabolic milieu is induced to restore the non-reproductive state (Kovacs 2016, Canul-Medina \& Fernandez-Mejia 2019, Jena et al. 2019).

In pregnancy, the glucose supply to the fetus depends on the maternal balance of insulin resistance and the capacity of beta cells to expand their mass, insulin production and secretion. There is extensive research https://joe.bioscientifica.com https://doi.org/10.1530/JOE-20-0184 (c) 2021 Society for Endocrinology Published by Bioscientifica Ltd.
Printed in Great Britain 
documenting the pancreatic islets' adaption to the insulin demand by increasing their size, the number of beta cells as well as the insulin secretion capacity (Rieck \& Kaestner 2010, Nielsen 2016), and that these changes depend on lactogenic hormones (Parsons et al. 1992, Brelje et al. 1993, Sorenson \& Brelje 1997, Baeyens et al. 2016). Further, beta-cell lactogen-induced serotonin (5-hydroxytryptamine) is also involved in the islet changes in pregnancy (Kim et al. 2010, Ohara et al. 2013); other signals such as miRNA (Jacovetti et al. 2012), EGF (Hakonen et al. 2011), hepatocyte growth factor (Demirci et al. 2012) and yet unidentified signals also participate in the gestational pancreatic islet expansion (Baeyens et al. 2016). After delivery, the maternal endocrine pancreas rapidly returns to non-pregnant state (Scaglia et al. 1995, Teixeira et al. 2019).

During lactation, changes in maternal metabolism occur to fulfill the nutrient and mineral requirements for milk production (Kovacs 2016, Canul \& Fernandez 2019). Lactating rats present lower glucose and plasma insulin concentrations as compared to non-lactating rats (Marynissen et al. 1983, Burnol et al. 1986, 1987), which can be explained by the high rate of glucose utilization and increased insulin sensitivity in the mammary glands and liver (Williamson 1980, Burnol et al. 1986, Lee et al. 2003). Moreover, islets from lactating rats present reduced secretory capacity (Marynissen et al. 1985) and low insulinogenesis in response to hyperglycemic loads (Baaziz \& Curry 1993).

After lactation, the morphological, metabolic and hormonal changes that take place in gestation and lactation are reversed to re-establish the non-reproductive normal state (Kovacs 2016, Canul-Medina \& FernandezMejia 2019, Jena et al. 2019). In the post-weaning period, the maternal skeleton undergoes rapid changes to compensate for the demineralization of milk production that occurs during lactation (Ardeshirpour et al. 2007, Kovacs 2011, 2016); thus, a substantial increase in bone formation takes place for skeletal reconstruction. Glucose uptake is a determinant for osteoblast differentiation and bone formation (Wei et al. 2015); however, little is known about glucose metabolism and pancreatic islet changes after weaning. Low concentrations of serum glucose have been observed in rats on day 10 after lactation (Palou et al. 1982).

Currently, bone is recognized as an endocrine tissue that participates in systemic metabolism and glucose homeostasis through the release of humoral factors (Ferron et al. 2010, Lacombe et al. 2013, Karsenty 2017). Furthermore, several studies have supported the existence of a bone-pancreas axis through osteocalcin and insulin (Lee et al. 2007, Fulzele et al. 2010, Sullivan et al. 2013, Oldknow et al. 2015). Osteocalcin is a hormone synthesized by the osteoblasts (Ferron et al. 2010, Karsenty 2017) that has been used as a serum marker of bone formation and mineralization (Zoch et al. 2016). This hormone undergoes post-translational modifications, and in its undercarboxylated form (GLU-osteocalcin) it acts as a hormone promoting pancreatic beta-cell proliferation, insulin production and peripheral insulin sensitivity (Ferron et al. 2008, 2010, Zoch et al. 2016, Karsenty 2017). Osteoblasts, in turn, respond to insulin through its receptor signaling by increasing bone remodeling and the production and bioavailability of GLU-osteocalcin (Lee et al. 2007, Ferron et al. 2010, Fulzele et al. 2010, Oldknow et al. 2015).

We speculate that the post-weaning physiological state can modify islet morphology and glucose homeostasis; thus, in the present study, the effects of postlactation on the pancreatic islets, glucose homeostasis and concentrations of GLU-osteocalcin were investigated.

\section{Materials and methods}

\section{Experimental design}

Female C57BL/6NHHsd mice were housed in barrierand climate-controlled conditions under $12 \mathrm{~h}$ light:12 h darkness cycles and allowed free access to water and food (Envigo 2019S, Indianapolis, Indiana, USA) throughout the experiments. The mice were handled according to the principles of laboratory animal care (NOM-062-ZOO1999; www.ncbi.nlm.nih.gov/books/NBK54050/). All the procedures were approved by the Ethical Committees for Experimentation at the Instituto Nacional de Pediatría (Project 031/2015) and at the Instituto de Investigaciones Biomédicas, Universidad Nacional Autónoma de México. For each lot, ten female mice aged 9 weeks were housed with male mice (two females with one male, for each mating). After 3 days of cohabitation, the males were removed from the cages. Mating was confirmed by the presence of a vaginal plug, which indicated day 0 of gestation (G0), and then pregnant mice were isolated in individual cages and randomly assigned to the different experimental groups. The mice of the age-matched virgin control group were housed in the same animal facility but did not undergo the reproductive procedure. On the day of delivery, the number of pups was adjusted to four to six pups per lactating mother, and the remaining neonates were anesthetized and killed with Sevorane (Sevoflurane, 
Abbot Laboratories, Mexico). Lactation continued until 21 days after delivery; on this day and, subsequently, on the first, third, seventh and fourteenth day after lactation, the mice of the experimental groups and age-matched virgin control group were fasted for $12 \mathrm{~h}$ and anesthetized with Sevorane. An additional group of mice on their 19th day of lactation was included in some experiments. The blood and pancreas were obtained and processed as described subsequently, after which the mice were euthanized with Sevorane.

The pancreas of 30 mice was studied for islets' morphometrics and insulin secretion. Glucose tolerance test was carried out on 65 mice, and 73 mice were tested for insulin tolerance. Insulin secretion was evaluated in 24 mice. GLU-osteocalcin was measured in serum samples of 44 mice, while 84 mice were studied for calcium concentrations in serum samples serotonin was assessed in the pancreas sections of 26 mice.

\section{Histological analysis}

The pancreas of each mouse was removed and immersed in $4 \%$ formalin-PBS for $6 \mathrm{~h}$ at room temperature, after which they were dehydrated and embedded in paraffin. Immunohistochemistry staining was conducted in consecutive $2-\mu \mathrm{m}$-thick sections mounted on glass slides. Slides with pancreatic sections were deparaffinized, rehydrated and unmasked in citrate-buffer at $90^{\circ} \mathrm{C}$ for $40 \mathrm{~min}$ for antigen retrieval. Next, the sections were permeabilized with $1 \%$ Triton X-100 (Calbiochem, Darmstadt, Germany), blocked with $2 \%$ goat serum and incubated overnight at $4^{\circ} \mathrm{C}$ with guinea-pig anti-insulin polyclonal antibody (1:100; Thermo Fisher Scientific \# PA1-26938) or mouse monoclonal anti-glucagon antibody (1:4000; Sigma \# G 2654). Sections were then washed and incubated with their respective secondary antibodies: Alexa Fluor488 Donkey Anti-Guinea Pig immunoglobulin G (IgG) or anti-mouse IgG Cy3-conjugated antibodies (Jackson Immuno Research Laboratories). Nuclei were stained with 4',6'-diamidino-2-phenylindole dihydrochloride (DAPI, Sigma) for cell number counting. Morphometric analysis of the islets was performed on the whole longitudinal sections of the pancreas (Montanya \& Téllez 2009), over a total mean area of $43.8 \pm 1.42 \mathrm{~mm}^{2}$. The analysis involved all the lobes. To avoid bias, the analysis was performed independently by three persons who were blinded to the group identity.

The areas of islets and cell islets were quantified using an Olympus IX71 microscope coupled with a digital camera (Olympus DP72) under magnification of 20X.
Total pancreatic sections were assessed with Olympus BX51-WI DSU at $4 \mathrm{X}$ using an attached Hamamatsu C9100 camera EM-CCD (Hamamatsu City, Japan). All images were captured with identical configuration settings.

Islet areas were obtained using manual tracing. Clusters of less than five insulin expressing cells were not considered in the islet analysis (Montanya \& Téllez 2009, Beamish et al. 2017). The islet fraction was measured as the ratio of the islet areas to the total pancreatic tissue area on the entire section (Toselli et al. 2014). For the analysis of size distribution, islets were classified as small $\left(<10,000 \mu \mathrm{m}^{2}\right.$ area $)$, medium $\left(10,000-25,000 \mu^{2}\right.$ area $)$ or large $\left(\geq 25,000 \mu \mathrm{m}^{2}\right.$ area $)$ (Vasu et al. 2014). The results represent the average of 280-320 islets from three to four tissue sections (per animal) of four to six animals in each group.

\section{Size and number of cells per isle}

Alpha and beta cells from islets classified as small, medium or large (Vasu et al. 2014) and from the same immunostaining sections utilized for the islet area and islet area frequency analyses were used in the studies to determine the size and number of cells per islet. Determination of individual cell area required the identification of glucagon- or insulin-positive cells and was carried out by manual tracing of the perimeter glucagon- and insulin-positive immunostaining of each islet. Then, the cell area was divided by the number of nuclei in each islet assessed by DAPI to obtain the mean of the individual alpha- and beta-cell areas, as described by (Scaglia et al. 1995, Montanya \& Téllez 2009).

To determine the number of cells per islet, DAPI immunostaining nuclei per insulin- or glucagon-positive cell was counted at a magnification of $20 \mathrm{X}$.

The results represent the average of randomly chosen 150-200 islets from two to three tissue sections (per animal) of four to six animals in each group. All the image analyses were performed using Image J 1.40 software (Research Services Branch, National Institute of Mental Health, Bethesda, MD, USA).

\section{Islet-cell proliferation}

Proliferation was evaluated by measuring the nuclear expression of Ki67 with the Novolink Polymer detection system Novocastra RE7260-CC (Leica). Briefly, 2- $\mu$ m-thick deparaffinized sections were unmasked in citrate buffer and placed in a pressure chamber at $121^{\circ} \mathrm{C}$ for $30 \mathrm{~s}$ for antigen retrieval. About $0.9 \%$ hydrogen peroxide was 
used for 5 min to block endogenous peroxidase activity. The sections were then incubated with rabbit monoclonal anti-Ki67 (1:100 clone Sp6 BioCare, Pacheco, CA, USA) for $45 \mathrm{~min}$ at room temperature, washed and incubated for 10 min with HRP-conjugated anti-rabbit IgG at room temperature. Ki67-positive cells were detected after using 3,3'-diaminobenzidine (BioCare, Pacheco, CA, USA) solution for $5 \mathrm{~min}$ and counterstaining with hematoxylin. The number of nuclei positive for Ki-67 was expressed as a percentage of the total number of nuclei per islet. The results represent the average of 116-136 islets from two to three tissue sections (per animal) of four to six animals in each group.

\section{Glucose tolerance test, insulin tolerance test and insulin secretion during glucose tolerance test}

Both glucose and insulin tolerance tests were performed between 09:00 and 10:30 h. For the glucose tolerance test, mice were fasted overnight $(12 \mathrm{~h})$ before the test and injected intraperitoneally with glucose $(2 \mathrm{~g} / \mathrm{kg}$ body weight). After the injection, blood glucose concentration was measured with a glucometer before and at 15, 30, 60, 90 and 120 min using tail vein blood (Glucometer Abbott Freestyle Optium, Mexico City, Mexico). For serum insulin concentrations during the glucose tolerance test, blood was collected from the tail vein at $0,5,20,30$ and $60 \mathrm{~min}$ during the glucose tolerance test for serum separation and insulin measurement, as previously reported (Lazo de la Vega et al. 2013).

For insulin tolerance tests, the mice had free access to food and water until the test. Soluble human insulin (1 IU/kg body weight) (Eli Lilly) was intraperitoneally injected. Blood samples were then taken before and at 15,30 and $60 \mathrm{~min}$ after the injection of insulin, and then blood glucose concentrations were measured with a glucometer, as described previously. Areas under the curves (AUCs) were calculated using Prism version 7 (GraphPad Software Inc.).

\section{Serum insulin, GLU-osteocalcin and calcium quantification}

Blood was collected from either cardiac puncture (for serum GLU-osteocalcin and calcium) or from the tail vein (insulin) and allowed to clot for $30 \mathrm{~min}$ at $20^{\circ}$. The clot was removed by centrifugation at $15,204 \mathrm{~g}$ and $4^{\circ} \mathrm{C}$ for 10 min, and the resulting supernatant was carefully removed using a Pasteur pipette and transferred into sterile tubes. Then, the sera were stored at $-70^{\circ} \mathrm{C}$.
Insulin concentrations were determined with a sensitive rat insulin EIA ELISA kit (ALPCO Catalog Number 80-INSRT-E0, Salem, NH, USA). The limits of detection were $21.4 \mathrm{pmol} / \mathrm{L}$.

GLU-osteocalcin was quantified using a mouse GLUosteocalcin high-sensitive EIA Kit (TAKARA BIO INC. Cat. \# MK129). The detection limit was $0.25 \mu \mathrm{g} / \mathrm{L}$. Absorbance was measured using the multi-detection microplate reader, Synergy HT BioTek (Winooski, Vermont, USA).

Serum calcium concentrations were measured by colorimetric assay using QuantiChrom Calcium Assay Kit (DICA-500) (BioAssay Systems, Hayward, CA, USA). All the measurements were performed according to the manufacturers' specifications.

\section{Islet serotonin analysis}

Islet serotonin content was assessed by immunofluorescence in sections of the pancreas of three to four mice as per the procedure described above. The sections were incubated overnight at $4^{\circ} \mathrm{C}$ with a rabbit polyclonal anti-5-HT (Serotonin) antibody (1:1000 InmunoStar, \#20080, Dublin, Ohio, USA), washed and incubated with Alexafluor594-Anti-rabbit G (IgG) (1:500) (Jackson Immuno Research Laboratories). The betacell serotonin content was expressed as a percentage of serotonin-positive beta cells per islet.

\section{Statistical analysis}

The data obtained are presented as means \pm s.E.M. All data points have been included. The statistical significance was determined by a one-way ANOVA with the post hoc Benjamini, Krieger and Yekutieli multiple comparison test. Statistical analysis was performed using the GraphPad Prism version 7 software. A significant difference was considered when $P \leq 0.05$.

\section{Results}

\section{Post-lactation effects on maternal body and pancreas weight}

Over a period of 14 days after weaning, the maternal body and pancreas weights were not significantly different between the age-matched control and experimental mice groups at the time of weaning or on the first, third, seventh or fourteenth day after weaning (Table 1). 
Table 1 Effects of post-lactation in mice on body and pancreas weight, blood glucose and serum insulin concentrations.

\begin{tabular}{l}
\hline \\
\hline Body weight (g) \\
Pancreas weight (mg) \\
Fasting blood glucose (mmol/L) \\
No-fasting blood glucose (mmol/L) \\
Fasting serum insulin (pmol/L)
\end{tabular}

\begin{tabular}{c}
\hline Control \\
\hline $23.4 \pm 0.36$ \\
$357 \pm 33.0$ \\
$4.95 \pm 0.17$ \\
$7.38 \pm 0.10$ \\
$50.0 \pm 2.76$ \\
\hline
\end{tabular}

\begin{tabular}{c}
\hline PLO \\
\hline $24.4 \pm 0.48$ \\
$389 \pm 24.7$ \\
$5.03 \pm 0.18$ \\
$6.99 \pm 0.35$ \\
$41.4 \pm 5.52$ \\
\hline
\end{tabular}

\begin{tabular}{c}
\hline PL1 \\
\hline $24.1 \pm 0.47$ \\
$375 \pm 15.0$ \\
$4.87 \pm 0.32$ \\
$7.10 \pm 0.23$ \\
$43.1 \pm 3.97$ \\
\hline
\end{tabular}

\begin{tabular}{c}
\hline \multicolumn{1}{c}{ PL3 } \\
\hline $23.8 \pm 0.32$ \\
$371 \pm 20.5$ \\
$5.88 \pm 0.17 \mathrm{a}$ \\
$6.72 \pm 0.08$ \\
$63.8 \pm 5.34^{b}$ \\
\hline
\end{tabular}

$\begin{array}{r}\hline \multicolumn{1}{c}{\text { PL7 }} \\ \hline 23.4 \pm 0.36 \\ 394 \pm 21.5 \\ 4.82 \pm 0.14 \\ 6.99 \pm 0.28 \\ 39.7 \pm 4.48 \\ \hline\end{array}$

\begin{tabular}{c}
\hline PL14 \\
\hline $24.6 \pm 0.33$ \\
$421 \pm 17.3$ \\
$5.34 \pm 0.26$ \\
$7.05 \pm 0.24$ \\
$41.4 \pm 7.24$ \\
\hline
\end{tabular}

Values are means \pm S.E.M. $n=11-14$ for body weight; $n=4-5$ for pancreas weight; $n=10-12$ for fasting blood glucose; $n=10-12$ for no-fasting blood glucose; $n=6-8$ fasting serum insulin. Superscript letters indicate significant differences $(P<0.05)$ compared to their respective control group. Key: Control age-matched virgin females mice and mice groups on the day of weaning (PL0) and 1 (PL1), 3 (PL3), 7 (PL7), and 14 days (PL14) after the end of lactation.

\section{Post-lactation effects on maternal islets' morphometry and morphology}

\section{Average area of pancreatic islets}

To determine whether the hormonal and physiological milieu modify islet morphology after weaning, the average area of the pancreatic islets of control mice vs the pancreatic areas on the first, third, seventh and fourteenth day after the end of lactation (PL1, PL3, PL7 and PL14) were compared. As shown in Fig. 1A and B, islet morphometry was modified after lactation. No significant difference was found between the average pancreatic islet size on the day of weaning ( $\mathrm{PLO}=8598 \pm 729 \mu \mathrm{m}^{2}$ ) and that observed in the control mice $\left(\right.$ control $\left.=8361 \pm 625 \mu \mathrm{m}^{2}\right)$. Subsequently, an increase was noticed in the average area of pancreatic islets. One day after weaning, a significant $(P \leq 0.005)$ increase of $42 \%$ was observed (PL1=12,239 $\pm 819 \mu \mathrm{m}^{2}$ ), which attained its maximal area on day 3 after the end of lactation (PL3 $\left.=15,102 \pm 986 \mu \mathrm{m}^{2} ; P<0.00005\right)$; thereafter, the islet size declined (PL7 $=11,017 \pm 829 \mu \mathrm{m}^{2} ; P<0.05$ ) to reach, after 14 days post-lactation, an area comparable to that found on the day of weaning (PL14 $=8250 \pm 909$ $\mu \mathrm{m}^{2}$ ). Representative images of the pancreatic islet areas are depicted in Fig. 1B.

\section{Frequency distribution of islets' area}

As compared to the control and day of weaning, on days 1 and 3 post-lactation, the proportion of small islets $\left(<10,000 \mu \mathrm{m}^{2}\right)$ decreased $(P<0.005)$ and the proportion of large islets $\left(>25,000 \mu \mathrm{m}^{2}\right)(P<0.005)$ increased $(P<0.005)$; both returned to the islet size-frequency distribution observed on the day of weaning and in the control mice by day 14 . No significant changes were observed in the proportion of medium islets (Fig. 2A).

\section{Islet fraction of total pancreatic area}

At the time of weaning, the islet fraction was not significantly different from that observed in the virgin mice (control $=0.42 \pm 0.058 \% ; \mathrm{PLO}=0.46 \pm 0.031 \%)$, but an augmentation was observed on days 1 and 3 after lactation

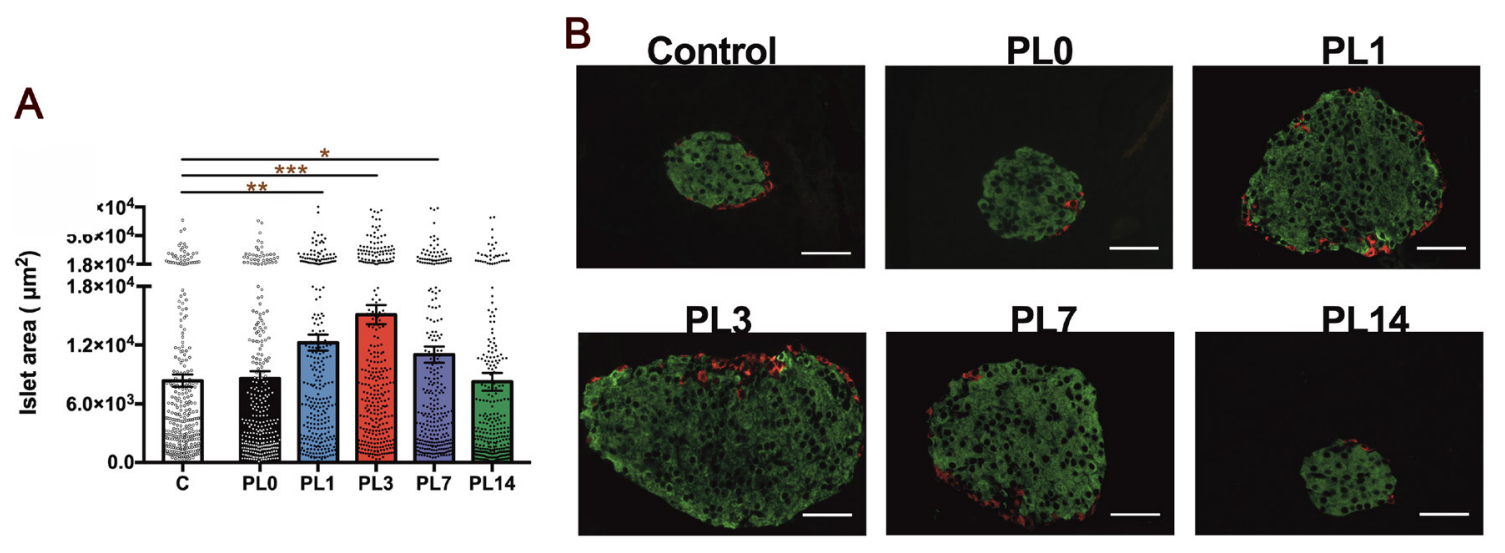

\section{Figure 1}

Pancreatic islet morphometry. Panel A: Individual data points show the area of each islet measured. Bars represent the average \pm S.E.M. of $280-320$ islets from four to six animals from pancreatic sections of age-matched virgin female control (C) and experimental mice groups: on the day of weaning (PL0) and 1 (PL1), 3 (PL3), 7 (PL7) and 14 days (PL14) after the end of lactation. $* P<0.05 ; * \star P<0.005 ; * \star \star P<0.0005$ compared to the control. Panel B: Representative immunofluorescence images of sections of pancreas stained for insulin (green) and glucagon (red) from age-matched virgin female mice (control), and experimental mice on the day of weaning (PL0) and 1 (PL1), 3 (PL3), 7 (PL7) and 14 days (PL14) after the end of lactation. The scale bar represents $50 \mu \mathrm{m}$. 
A
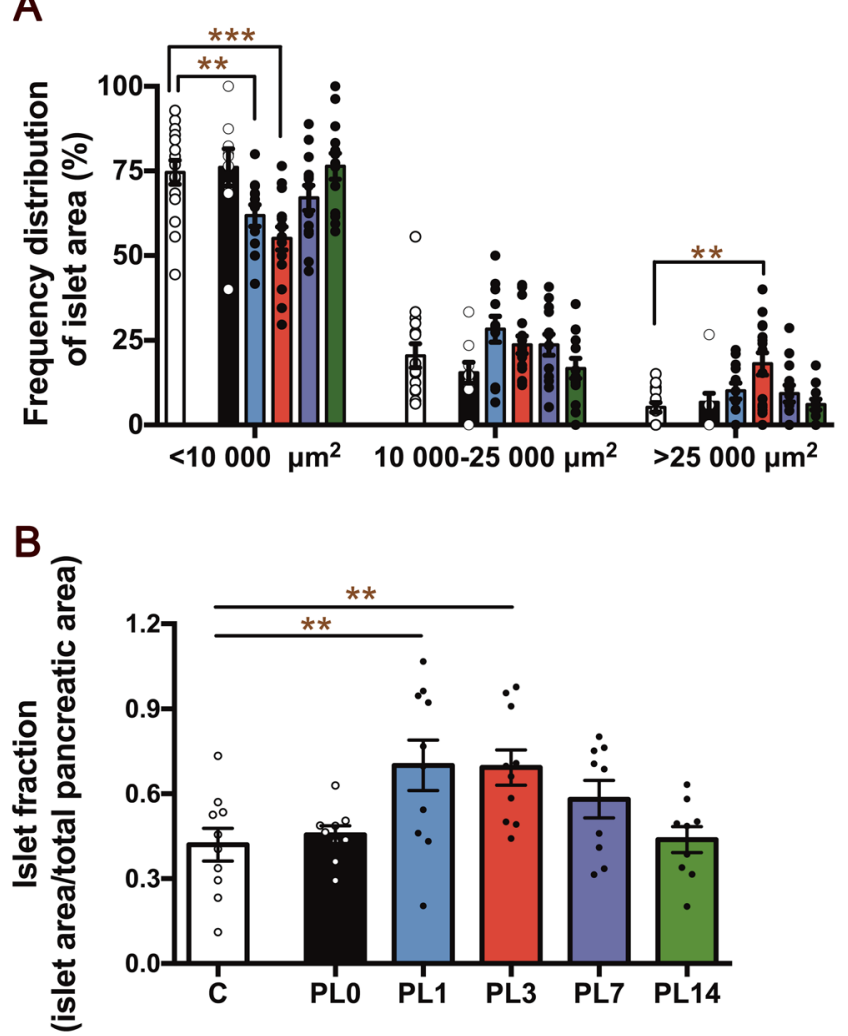

Figure 2

Pancreatic islet morphometry. Panel A: Individual data points show the frequency distribution percentage of islet area per pancreatic section. Bars represent the average \pm S.E.M. of 9-15 pancreatic sections per experimental group of the total number of measured islets. Key: Control (white), day of weaning (black) and after weaning: day 1 (blue), 3 (red), 7 (purple) and 14 (green) after the end of lactation. Panel B: Individual data points show the islet fraction of the total pancreatic area of age-matched virgin female controls $(C)$ and experimental mice on the day of weaning (PL0) and 1 (PL1), 3 (PL3), 7 (PL7) and 14 days (PL14) after the end of lactation. Bars represent the average \pm S.E.M. of 9-15 pancreatic slices per experimental group. ${ }^{\star *} P<0.005$; compared to the control.

$(\mathrm{PL} 1=0.70 \pm 0.09 \% ; \mathrm{PL3}=0.69 \pm 0.062 \% ; P<0.005)$, which subsequently decreased (PL7 $=0.58 \pm 0.066 \%$ ); on the 14th day post-lactation, it reached the islet fraction found on the day of weaning (PL14=0.44 $\pm 0.046 \%$ ) (Fig. 2B).

\section{Post-lactation effects on maternal beta- and alpha-cell islet composition}

\section{Islet beta-cell number}

The data revealed that the number of beta cells per islet starts to increase from the first day of lactation arrest $(\mathrm{PL} 1=100 \pm 8.52$; beta cells/islet; $P<0.005)$ and reaches the maximum extent on the third day post-lactation arrest $($ PL3 $=118 \pm 10.9$ beta cells/islet; $P<0.0005)$. On the seventh day post-lactation arrest, the number of beta cells per islet gradually decreases (PL7 $=83.6 \pm 8.56$ beta cells/islet) to reach a number similar to those found on the day of weaning and 14 days after the arrest of lactation (PL14 $=62 \pm 6.91$ beta cells/islet). No significant differences were observed between the beta-cell values in the control virgin mice (control=66.4 \pm 5.68 beta cells/ islet) and those on the day of weaning (PLO $=64.4 \pm 6.45$ beta cells/islet) (Fig. 3A).

\section{Beta-cell size}

The average size of individual beta cells (Fig. 3B) increases from the day of weaning (control=86.6 $\pm 2.62 \mu \mathrm{m}^{2}$; PLO $\left.=100 \pm 2.3 \mu \mathrm{m}^{2} ; P<0.0005\right)$, attaining maximal cell expansion on day 3 of the post-lactation period $\left(\right.$ PL3 $\left.=120 \pm 2.9 \mu \mathrm{m}^{2} ; P<0.0005\right)$. Contrary to most of the parameters measured, which returned to the concentrations observed in the control mice, the enhancement in beta-cell size persisted up to the 14 th day post-lactation $\left(\mathrm{PL} 14=113 \pm 3.01 \mu \mathrm{m}^{2} ; P<0.0005\right)$.

\section{Islet alpha-cell number}

The comparison of alpha-cell numbers per islet in the control mice and post-lactating mice showed that the number of glucagon-containing cells had significantly decreased $(P<0.0005)$ since the day of weaning and during the entire analyzed post-lactation period $($ control $=14.6 \pm 1.26 ;$ PLO = 7.40 $\pm 0.69 ;$ PL1 $=10.9 \pm 1.05$; PL3=9.35 $\pm 0.95 ;$ PL7=10.7 $\pm 1.40 ;$ PL14=8.05 \pm 1.14 alpha cell/islet; $P<0.005)$. Moreover, the number of alpha cells remained low on day 14 post-lactation (Fig. 3C).

\section{Alpha-cell size}

The average size of the individual alpha cells in the control virgin group was not significantly different from that of the mice on the day of weaning, but it subsequently increased slightly (6\%) and returned to the alpha cell size presented in the control group on the 14th day postlactation (Fig. 3D).

\section{Post-lactation effects on maternal islet-cell proliferation rate}

As shown in Fig. 4A and B, our studies revealed that, compared to the control virgin islets (control= $0.66 \pm 0.091 \%)$, the Ki67 cell proliferation marker significantly increased from the day of weaning $(\mathrm{PLO}=1.48 \pm 0.18 \% ; P<0.005)$. Comparable augmentation of the Ki67 marker to those observed on the day of weaning continued 1 and 3 days after the arrest of lactation $(\mathrm{PL} 1=1.35 \pm 0.24 \%$; PL3 $=1.23 \pm 0.18 \% ; P<0.05)$. 
A

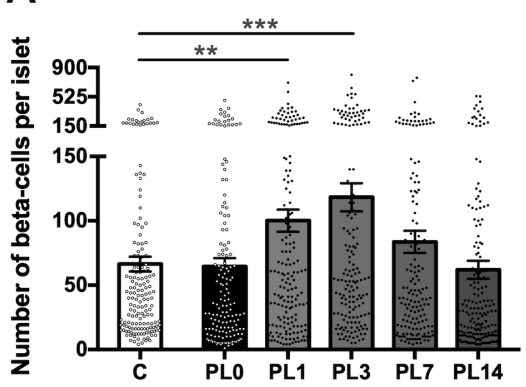

C

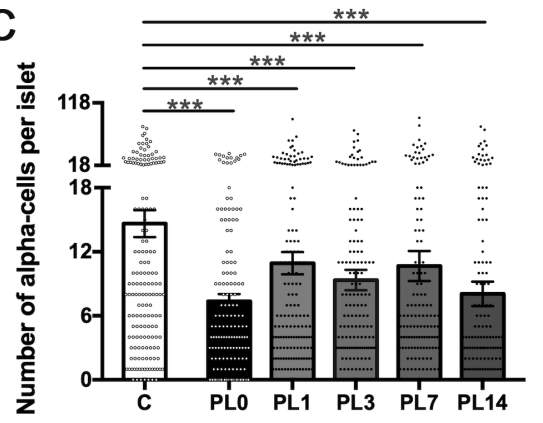

B
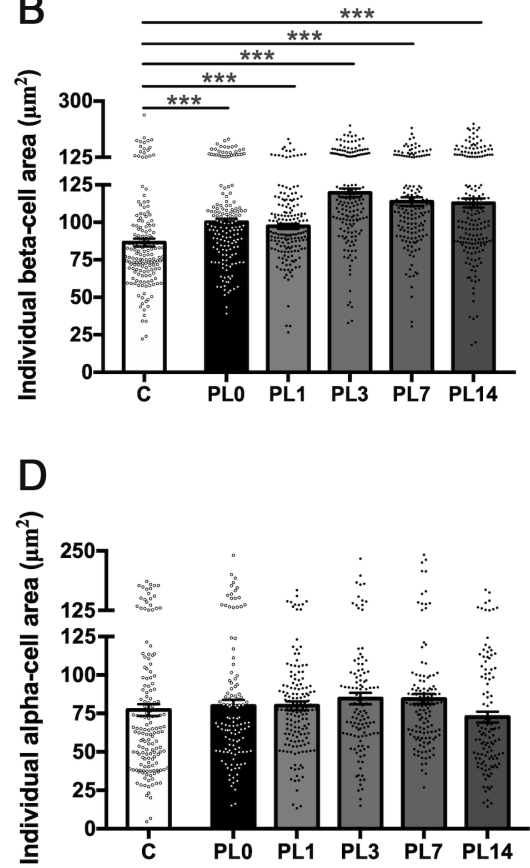

Figure 3

Pancreatic islet cells composition Individual data points show: Panel A: Number of beta cells per islet. Panel B: Individual beta-cell area. Panel C: Number of alpha cells per islet. Panel D: Individual alpha-cell area. Key: Age-matched virgin female controls (C), and experimental mice on the day of weaning (PL0) and 1 (PL1), 3 (PL3), 7 (PL7) and 14 days (PL14) after the end of lactation. Bars represent the average \pm S.E.M. of 150-200 randomly chosen islets from two to three tissue sections (per animal) of four to six mice in each group. ${ }^{* \star} P<0.005 ;{ }^{*} * P<0.0005$ compared to the control.
On days 7 and 14 post-lactation, the proliferation decayed to values under those observed in the control virgin mice $(\mathrm{PL7}=0.47 \pm 0.088 \% ; \quad P>0.05 ; \quad \mathrm{PL} 14=0.33 \pm 0.083 \%$; $P<0.05)$. Apart from the increase in cell proliferation from the day of weaning, the percentage of Ki67 positive cells 2 days before weaning was also determined. Our data revealed that cell proliferation increased (L19=1.50 $\pm 0.18 \% ; P<0.005)$, and the augmentation was similar to those observed on the day of weaning and on the following 3 days post-lactation.

\section{Post-lactation effects on maternal glucose homeostasis}

\section{Blood glucose concentration}

No differences in the fasting or non-fasting blood glucose were observed between the virgin mice and postlactating mothers on the day of weaning and on days 1 , 7 and 14 after lactation; however, a significant increase $(P<0.005)$ in fasting blood glucose was found on the third day (Table 1).

\section{Glucose tolerance}

Comparison of the control and post-weaning mice groups revealed enhanced glucose tolerance from the day of weaning and during the first 7 days post-lactation $(P<0.05)$; on day 14 post-lactation, the glucose tolerance values presented in the control virgin mice were recovered (Fig. 5A). The mean areas under the curve on different days of the study were as follows: control $=42.4 \pm 1.86$; $\mathrm{PLO}=36.0 \pm 1.53 ; \mathrm{PL} 1=35.2 \pm 1.40 ; \mathrm{PL} 3=35.9 \pm 1.18 ;$ $\mathrm{PL7}=34.7 \pm 1.09 ; \mathrm{PL} 14=38.7 \pm 2.21 \mathrm{mmol} / \mathrm{L} \times$ minute (Fig. 5B).

\section{Insulin tolerance}

No differences were observed in the area under the curve for insulin tolerance tests between the control group (control=185 \pm 6.34) and the day of weaning $(\mathrm{PLO}=193 \pm 5.64 \mathrm{pmol} / \mathrm{L} \times$ minute $) ;$ however, on the day following weaning, a significant decrease $(P<0.005)$ was found in insulin sensitivity, which progressed up to the third day post-weaning (PL1=209 \pm 4.58 ; $\mathrm{PL} 3=223 \pm 5.20 \mathrm{pmol} / \mathrm{L} \mathrm{min} ; P<0.005)$ to subsequently attain the concentrations observed in the control and on the day of weaning (PL7=182 $\pm 5.68 ;$ PL14=199 \pm 5.43 $\mathrm{pmol} / \mathrm{L} \mathrm{min)}$ (Fig. 5C and D).

\section{Basal insulin and induced insulin secretion in vivo}

Studies were carried out to ascertain how the postlactation physiological environment affects insulin secretion. Compared to the control mice, fasting insulin concentrations increased 27\% $(P<0.05)$ on the third day after the cessation of lactation (Table 1); after the glucose challenge and during the glucose tolerance test (Fig. 5E and F), our data revealed higher insulin concentrations $(P<0.005)$ on the third day after lactation. No differences were observed between the control virgin group and the day of weaning or days 1 , 
A

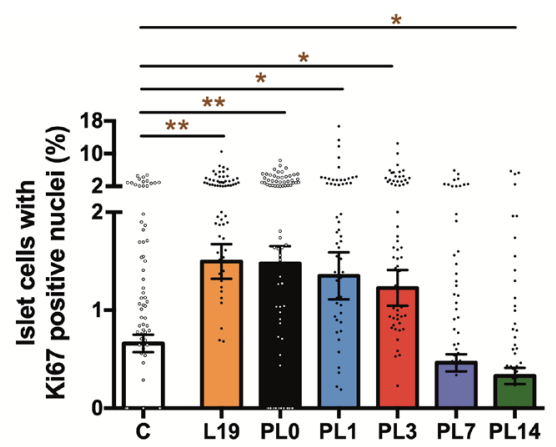

B

\section{Control}

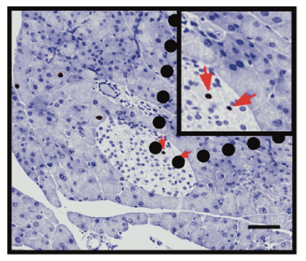

L19

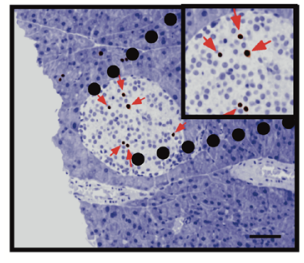

PL3

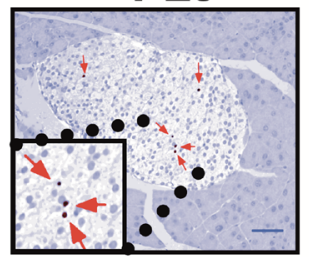

PLO

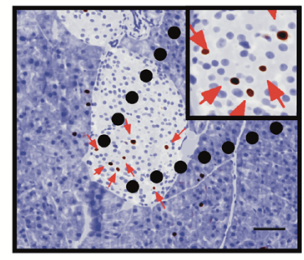

PL7

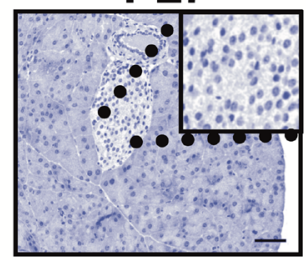

PL1

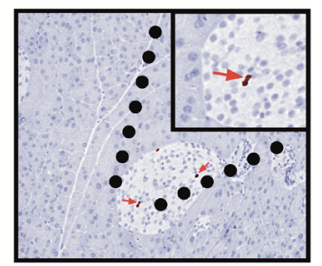

PL14

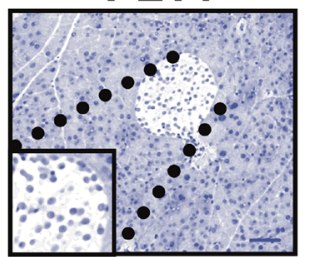

Figure 4

Pancreatic islet cells proliferation. Panel A: Individual data points of the percentage of cells stained for antigen Ki67 positive nuclei out of the total number of islet nuclei. Bars represent the mean \pm S.E.M. of four to six mice from each group. Key: Age-matched virgin female control (C) and experimental mice groups on the 19th day of lactation (L19), the day of weaning (PLO) and 1 (PL1), 3 (PL3), 7 (PL7) and 14 days (PL14) after the end of lactation. $* P<0.05 ; * * P<0.005$ compared to the control. Panel B: Representative images of Ki67 positive nuclei in the pancreatic islet. Arrows indicate Ki67 (brown) positive cells. Scale bar: $50 \mu \mathrm{m}$.
7 and 14 after the cessation of lactation. The blunted glucose-induced insulin secretion on the seventh day after weaning (Fig. 5E) coincided with the higher insulin sensitivity observed in the insulin tolerance test (Fig. 5C and D).

\section{Post-lactation effects on maternal serum GLU-osteocalcin}

The central physiological function of bone remineralization after lactation and the recognized hormonal communication between beta cells and bones via GLU-osteocalcin prompted the investigation of the concentrations of this hormone (Fig. 6A). Compared to the control group (control=1.97 $\pm 0.16 \mu \mathrm{g} / \mathrm{L}$ ), no significant difference was observed on the day of weaning $(\mathrm{PLO}=2.82 \pm 0.25 \mu \mathrm{g} / \mathrm{L})$, but significant augmentation of GLU-osteocalcin was observed from the first day post-lactation (PL1=3.61 $\pm 0.35 \mu \mathrm{g} / \mathrm{L}$; $P<0.005)$; it reached maximum values on the third day after weaning $(\mathrm{PL} 3=4.47 \pm 0.68 \mu \mathrm{g} / \mathrm{L} ; P<0.0005)$ and decreased to the concentrations found in the control mice on days 7 and 14 after lactation $(P L 7=2.38 \pm 0.36 \mu \mathrm{g} / \mathrm{L}$; PL14=2.32 $\pm 0.27 \mu \mathrm{g} / \mathrm{L})$. Since GLU-osteocalcin increases beta-cell proliferation and it was found that proliferation occurs before weaning, its concentrations were also determined 2 days before the cessation of lactation. The data revealed that on day 19 of lactation, GLU-osteocalcin concentrations $(\mathrm{L} 19=1.63 \pm 0.14 \mu \mathrm{g} / \mathrm{L})$ were not different from those observed in the control mice. 
A
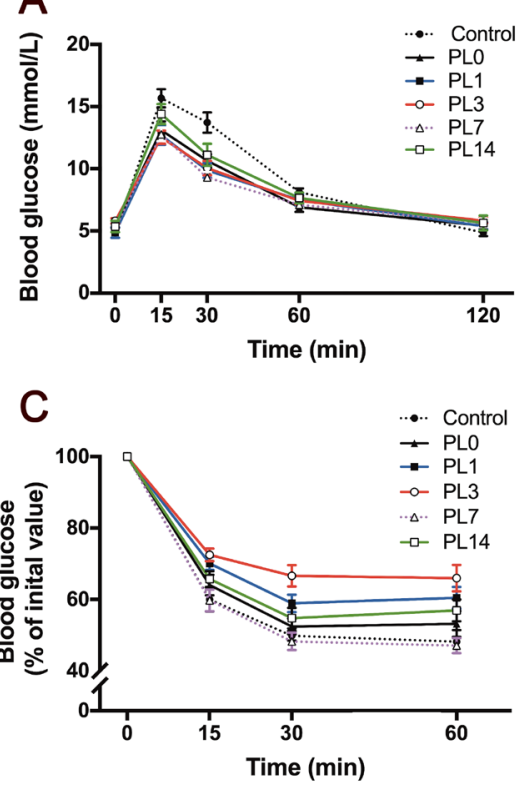

$E$

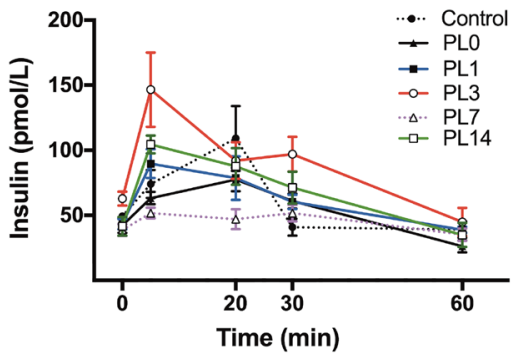

B

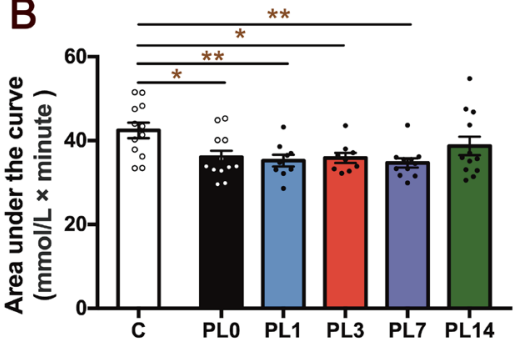

D

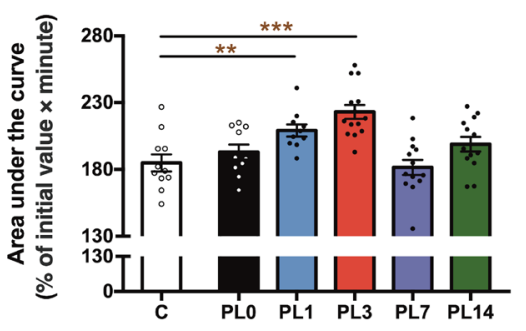

F

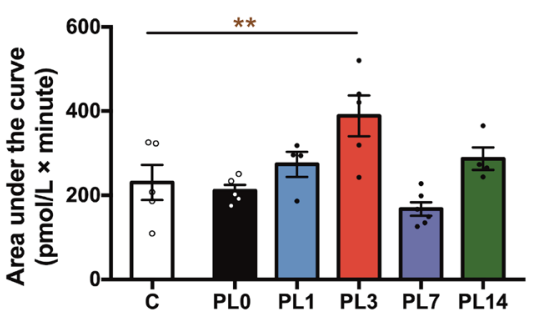

\section{Figure 5}

Glucose and insulin tolerance tests and in vivo insulin secretion. Panel A: Blood glucose concentration during intraperitoneal glucose tolerance test. Panel B: Individual data points show the area under the curve of glucose tolerance test per mouse. Bars represent the mean \pm S.E.M. of 9-12 mice from each group. Panel C: Percentages of basal ( $0 \mathrm{~min}$ ) blood glucose concentration during the intraperitoneal insulin tolerance test. Panel D: Individual data points show the area under the curve of insulin tolerance test per mouse. Bars represent the mean \pm S.E.M. of 10-14 mice from each group. Panel E: Serum insulin concentration during intraperitoneal glucose tolerance test. Panel F: Individual data points of the area under the curve of serum insulin concentration during intraperitoneal glucose tolerance test per mouse. Bars represent the mean \pm S.E.M. of four to six mice from each group. Key: Age-matched virgin female controls (C), experimental mice on day of weaning (PL0) and 1 (PL1), 3 (PL3), 7 (PL7) and 14 days (PL14) after the end of lactation. $* P<0.05$;

$\star \star P<0.005 ; * \star * P<0.0005$ compared to the control.

\section{Post-lactation effects on maternal serum calcium concentrations}

Weaning is associated with transient hypercalcemia (Ardeshirpour et al. 2007, Kovacs 2016). Therefore, we also investigated serum calcium concentrations (Fig. 6B). Compared to the control group (control=2.21 \pm 0.03 $\mathrm{mmol} / \mathrm{L}$ ), moderate augmentation of circulating calcium of about $15-19 \%$ was observed from the 19th day of lactation to 1 day after weaning $(\mathrm{L} 19=2.63 \pm 0.12 ; \mathrm{PLO}=2.63 \pm 0.09$; $\mathrm{PL} 1=2.53 \pm 0.10 \mathrm{mmol} / \mathrm{L} ; P<0.05)$, decreasing afterward to controlconcentrations $(\mathrm{PL} 3=2.33 \pm 0.07 ; \mathrm{PL7}=2.29 \pm 0.07$ ); an upturn of serum calcium concentrations was observed on the 14th day after lactation (PL14=2.52 \pm 0.08 $\mathrm{mmol} / \mathrm{L} ; P<0.05$ ).

\section{Post-lactation effects on maternal beta cells' serotonin content}

Serotonin produced locally in the pancreatic islets participates in beta-cell proliferation and insulin secretion during pregnancy (Kim et al. 2010). Hence, the islet serotonin content was investigated over 14 days postweaning; sections of the pancreas of control mice on day 14 of pregnancy as well as day 19 of lactation - the day when proliferation was observed - were included. As shown in Fig. 7, the age-matched control group lacked serotonin-positive cells, in contrast the islets of the pregnant mice presented serotonin-containing cells in profusion, the value of which fell noticeably during lactation (day 19 of lactation: $\mathrm{L} 19=8.04 \pm 0.64 \%$; $P<0.0005$ ), decreasing afterward (PLO $=3.11 \pm 0.45$; $\mathrm{PL} 1=1.10 \pm 0.37 ; \mathrm{PL} 3=0.80 \pm 0.26 ; \mathrm{PL} 7=0.11 \pm 0.076$; PL14 $=0.035 \pm 0.035$ ).

\section{Discussion}

During gestation and lactation, hormones orchestrate changes in tissue morphology and metabolism to provide development and growth for the infant. These changes are reversed after weaning - a period in which the new hormonal and metabolic environment shifts toward the rapid restoration of the non-reproductive 

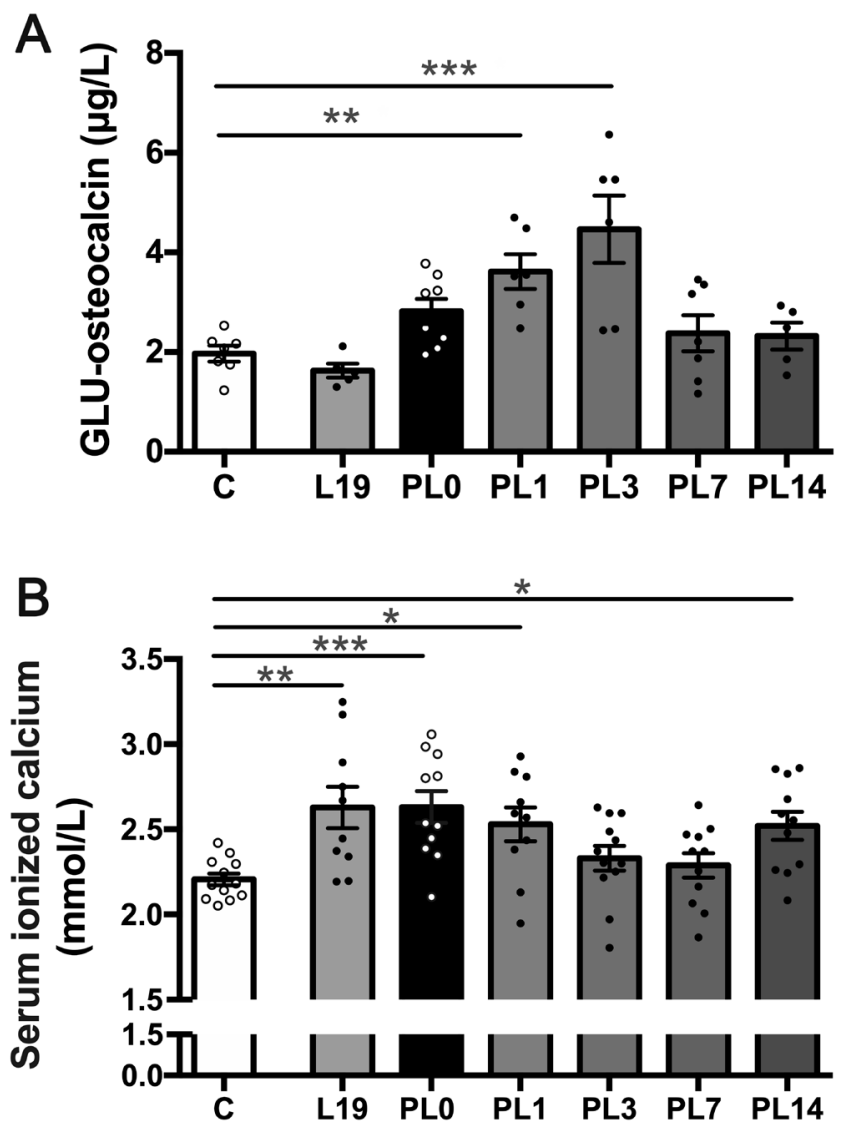

\section{Figure 6}

Serum GLU-osteocalcin and serum ionized calcium concentrations. Panel A: Individual data points show serum GLU-osteocalcin concentration per mouse. Bars represent the mean \pm S.E.M. of five to eight mice from each group. Panel B: Individual data points show serum ionized calcium concentration per mouse. Bars represent the mean \pm S.E.M. of 10-12 mice from each group. Key: Age-matched virgin female controls (C) and experimental mice groups on the 19th day of lactation (L19), the day of weaning (PL0) and 1 (PL1), 3 (PL3), 7 (PL7) and 14 days (PL14) after the end of lactation. $* P<0.05 ; * \star P<0.005 ; * \star \star P<0.0005$ compared to the control.

state, particularly in terms of bone remineralization and mammary gland involution (Kovacs 2016, CanulMedina \& Fernandez-Mejia 2019, Jena et al. 2019). Likewise, in the course of gestation and lactation, glucose homeostasis and beta-cell mass are modified (Marynissen et al. 1983, 1985, Burnol et al. 1986, 1987, Baaziz \& Curry 1993, Rieck \& Kaestner 2010, Baeyens et al. 2016, Nielsen 2016). However, little is known about pancreatic islet morphology and glucose metabolic changes after lactation. Filling this gap, the present study reported, for the first time, that glucose homeostasis is modified and pancreatic islet morphology and insulin secretion undergo enhancement in the post-lactation period. Our data revealed striking and rapid changes in the endocrine pancreas just 1 day after cessation of lactation; the area maximum values were reached on day 3 after weaning and later decrease.

No significant differences were observed in the islet size on the day of weaning as compared to the control group. This result is in accordance with a pioneer study in rats by Marynissen et al. (1983), showing no difference in islet cell area between the virgin group and mothers at the end of lactation. As early as 1 day after weaning, this study found that the islet area, pancreatic islet fraction and number of beta cells increased by about 50\%. On the third day after the cessation of lactation, we observed a further increase in islet area, which was due to an extensive increase in the beta cell numbers and a moderate increase in beta-cell size. Alpha cell area also increased (6\%), while the alpha cell numbers decreased.

The magnitude increase of the maximum postlactation islet size is comparable to the augmentation of islet mass that takes place in pregnant rodents (Huang et al. 2009). As in gestation, both hyperplasia and hypertrophy of islet cells participate in post-weaning islet size enlargement (Huang et al. 2009, Xu et al. 2015, Dirice et al. 2019, Quesada et al. 2020).

After the third day post-lactation, this study found that the islet area, fraction, frequency distribution of islet size, the number of beta cells per islet and individual alpha-cell area progressively reduced, and on day 14 post-lactation, values similar to those observed in the control mice were attained. Two characteristics that did not return to basal control concentrations were the individual beta-cell area, which remained at over 30\% the size in the control mice, and the number of alpha cells per islet, which was 55\% lesser than that in the control mice. It is interesting to note that both features were observed to have already been modified on the day of weaning. Further studies will be required to determine the time span involved in returning to the concentrations of the control group and whether these characteristics persist in a modified state after a reproductive cycle of gestation and lactation.

Our data revealing that islet cell proliferation had already increased 2 days before the cessation of lactation, along with the observation that the number of alpha cells and the beta-cell size were modified from the day of weaning, suggest that a series of events take place throughout lactation to prepare the endocrine pancreas for the adaptations that occur post-lactation. This condition resembles the increase in beta-cell replication and beta-cell hypertrophy that occur during two-thirds of the gestation period, anteceding the metabolic and islet mass increase that occurs in the third period of pregnancy (Rieck \& Kaestner 2010, Baeyens et al. 2016). 


\section{Journal of Endocrinology}

A

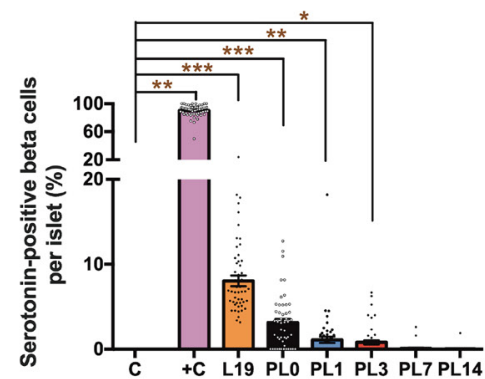

B

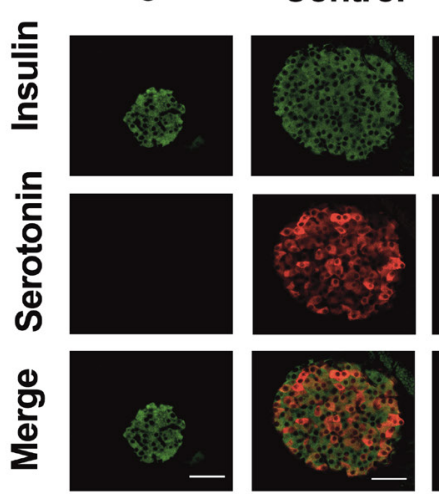

L19
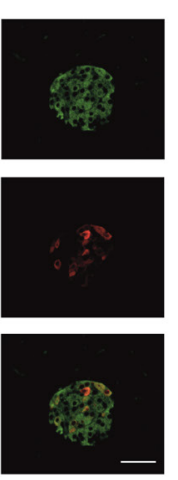

PLO
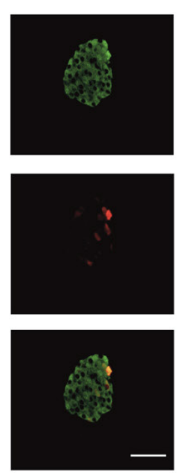

PL1
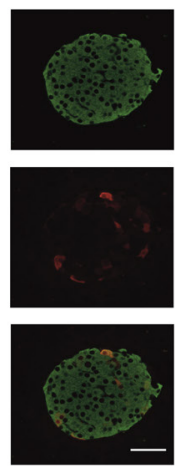

PL3

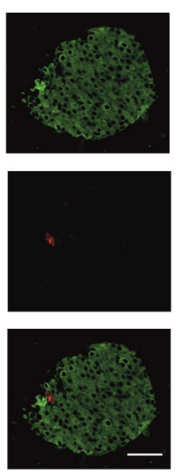

Figure 7

Pancreatic islet serotonin content. Panel A: Individual data points show the percentage of serotonin-positive beta cells per islet. Bars represent the average \pm S.E.M. of islet serotonin content of 46-60 islets from three animals from each group. $* P<0.05 ; * \star P<0.005 ; * \star \star P<0.0005$ compared to the age-matched virgin female controls (C). Panel B. Representative immunofluorescence images of pancreatic islet serotonin content in age-matched virgin female controls and experimental mice on the 14th day of gestation (+C), 19th day of lactation (L19), day of weaning (PL0) as well as 1 (PL1) and 3 days (PL3) after the end of lactation. The scale bar represents $50 \mu \mathrm{m}$.

Likewise, as observed during the involution of islet cell mass from pregnancy to post-partum in rats (Scaglia et al. 1995), our results revealed that after the day on which the islets attained their maximum area, islet-cell proliferation decreased below the proliferation values observed in virgin mice. These findings show the similarities between the changes of islet mass in pregnancy and post-lactation.

The pancreatic islet changes observed during the first 3 days after weaning were accompanied with a progressive decrease in insulin sensitivity and increased glucose- induced insulin secretion, indicating insulin resistance. Notwithstanding these changes, glucose concentrations during the glucose tolerance test decreased from the day of weaning and remained significantly lower during the first week after the cessation of lactation. In rats, low concentrations of serum glucose have been observed on day 10 after lactation (Palou et al. 1982). The coexistence of insulin resistance and increased glucose tolerance has been observed in late pregnancy (20 days) in rats (Carrara et al. 2012) as a physiological mechanism to maintain
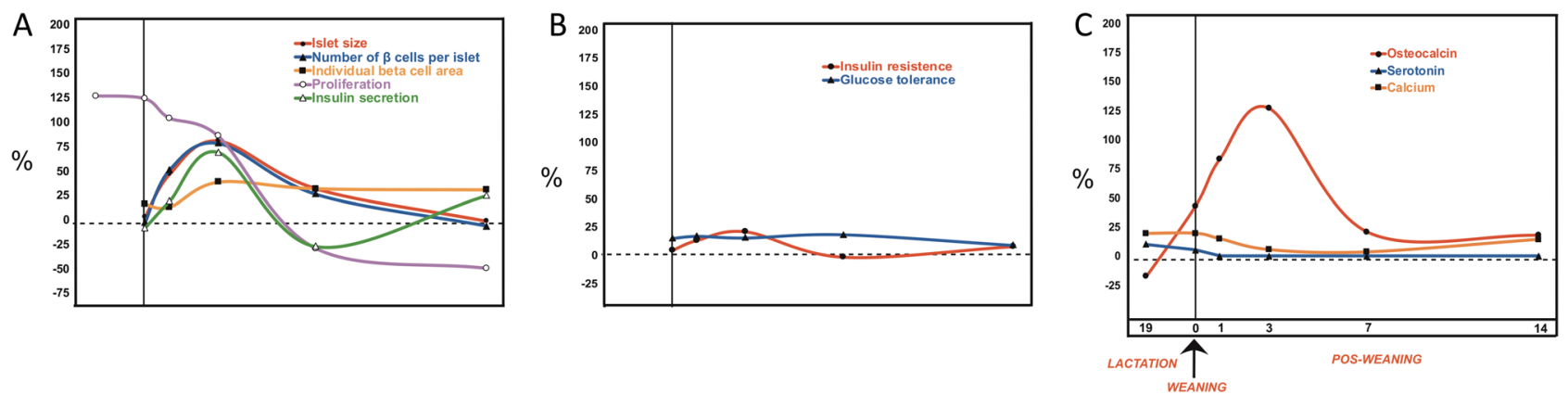

\section{Figure 8}

Time course changes in islet morphology, glucose metabolism, serum calcium concentrations and hormones. The scheme depicts the percentage variations of islet morphology, insulin secretion, glucose homeostasis, undercarboxylated osteocalcin, serum ionized calcium and serotonin between the control age-matched virgin female group vs the mice groups on either the day of weaning or over 14 days post-lactation. After weaning, a rapid enlargement of islet size occurs, which is in concordance with the rise of beta-cell numbers; these changes attained maximal values on the third day post-lactation and were accompanied by augmented glucose-induced insulin secretion and serum concentrations of GLU-osteocalcin but decreased insulin sensitivity and serum calcium concentrations. Islet-cell proliferation had already increased 2 days before weaning (day 19 of lactation) and was unrelated to increased GLU-osteocalcin concentrations or the abundance of islet serotonin content. A modest increase in beta-cell size and glucose tolerance was present from the day of weaning. Fourteen days after weaning, the islet size, beta-cell number, insulin secretion, glucose and insulin tolerance and GLU-osteocalcin concentrations returned to those observed in the control mice, but the beta-cell area remained increased, and an upturn in serum calcium concentrations was observed. In addition, cell proliferation, which had increased prior to weaning, endured a significant decrease on days 7 and 14 post-lactation. Panel A. Islet morphology and insulin secretion; Panel B. Glucose homeostasis; Panel C. Serum calcium concentrations, GLU-osteocalcin and serotonin. 
blood glucose concentrations in the face of intense glucose utilization by the fetus. In a similar manner, our present results suggest that an intense glucose uptake takes place despite insulin resistance. As weaning initiates a rapid and powerful anabolic phase with an increase in the formation of osteoblasts occurring immediately after the cessation of lactation (Miller et al. 2005) and since glucose is an important source of energy for osteoblasts (Wei et al. 2015), the low glucose concentrations in the glucose tolerance test are likely to be the result of its profuse uptake by the bone. Furthermore, glucose is taken up avidly by these cells in an insulin-independent manner through GLUT1 (Wei et al. 2015), a transporter whose expression favors the expression of osteocalcin (Wei et al. 2015, Takeno et al. 2018), a hormone that is released in its undercarboxylated form, promoting pancreatic beta-cell proliferation (Ferron et al. 2008, 2010, Zoch et al. 2016, Karsenty 2017).

The analysis of serum GLU-osteocalcin concentrations revealed that this hormone had not increased 2 days before the cessation of lactation but was augmented post-lactation, attaining maximal increase on the third day after lactation and decreasing subsequently. Similar results were found by Ardeshirpour et al. (2007) and Kirby et al. (2011), coinciding with the significant mineral gains in the spine and total body bone that are observed as early as 3 days after the end of lactation (Ardeshirpour et al. 2007). The time course of the serum GLU-osteocalcin increase observed in the present study suggests that the osteo-insulin axis via metabolic active osteocalcin might take part in insulin release post-lactation. However, the fact that cell proliferation was enhanced before the increase of GLU-osteocalcin makes the action of the hormone in the augmentation of islet-cell proliferation unlikely. Furthermore, this bone hormone has been reported to increase insulin sensitivity (Lee et al. 2007, Ferron et al. 2008), which contrasts with the decrease observed in insulin sensitivity in the present study. Taken together, it is difficult at this point to evaluate the role of GLU-osteocalcin in the metabolic and pancreatic islet modifications that occur in post-lactation, suggesting that other bone factors might participate in the postweaning changes; indeed, investigations have found that additional bone-derived hormones may contribute to the function of the skeleton as a metabolic regulator (Yoshikawa et al. 2011, Gillespie et al. 2013, Yao et al. 2017, Dirckx et al. 2018). Additionally, it might be possible that factors from other tissues could potentially (CanulMedina \& Fernandez-Mejia 2019) participate in the islet and metabolism modifications observed after weaning
(Canul-Medina \& Fernandez-Mejia 2019). Further studies will be required to determine the role of other tissues in pancreatic islet changes after weaning.

Transient hypercalcemia occurs over the first several days of weaning (Ardeshirpour et al. 2007, Kovacs 2016). In the pancreatic cell line MIN6, studies by Hills et al. (Hills et al. 2012, Squires et al. 2014) have indicated that extracellular calcium via the islet calcium-sensing receptor may maintain and increase beta-cell mass and augment insulin secretion. In the present study, we found a transient calcium increase, albeit in the normal range, from day 19 of lactation up to 1 day after weaning, a period which partially corresponded with the pancreatic cells' proliferation rate increases (19th day of lactation to the third day post-lactation); however, the calcium upturn on the 14th day post-lactation coincided with the lowest proliferation rate. This time-course pattern and the lack of parallelism between serum calcium increases and insulin secretion changes make it improbable that serum calcium concentrations participate in the islet pancreatic changes observed.

Placental lactogen- and prolactin-induced serotonin produced in the islet have been recognized as factors leading to the increase of insulin secretion and beta-cell proliferation via their shared receptor during pregnancy (Kim et al. 2010, Ohara et al. 2013, Baeyens et al. 2016). In post-lactation, prolactin returns to the basal concentrations (Kovacs 2016, Canul-Medina \& FernandezMejia 2019), and serotonin synthesis in the islet may reduce, as demonstrated in our study. This diminution renders unlikely a role for serotonin in the changes that take place in the islets after weaning. Further studies are essential to determine the signals that participate in islet enhancement and glucose metabolism post-lactation.

In summary (Fig. 8), the present work demonstrates, for the first time, that glucose homeostasis is modified after weaning, and pancreatic islets undergo remarkable morphological changes and augmented insulin secretion. These changes are accompanied by increased concentrations of GLU-osteocalcin; however, the hormone changes cannot explain the earlier enhancement in islet-cell proliferation, indicating that other hormones and factors might be involved in the changes observed post-lactation.

The number of patients with diabetes has greatly increased over the past several decades (International Diabetes Federation 2019). Thus, interventions to prevent and control this disease are of particular clinical importance. Extensive evidence indicates that decreased islet mass and insulin secretion are two critical factors that characterize the development of type 1 and type 2 
diabetes (Weir et al. 2001, Meier \& Bonadonna 2013, Hudish et al. 2019). The findings of the present work recognize a physiological period in which the beta-cell enhancement and insulin release take place, opening up a new field with wide-ranging opportunities to identify the molecules and mechanisms participating in these processes; this knowledge will help in the development of new therapeutic strategies for the prevention and treatment of diabetes, a major health problem worldwide.

\section{Declaration of interest}

The authors declare that there is no conflict of interest that could be perceived as prejudicing the impartiality of the research reported.

\section{Funding}

This work was supported by Dirección General de Asuntos del Personal Académico (DGAPA), Universidad Nacional Autónoma de México (PAPIIT: IN 206617); by Fondos Federales, Recursos Fiscales 2017 (number 031/2015), and by Consejo Nacional de Ciencia y Tecnología (CONACyT, Ciencia Básica A1-S-10101). Gustavo Canul-Medina is a Ph.D. student from the Doctorado en Ciencias Biomédicas at the Universidad Nacional Autónoma de México and had a scholarship from CONACYT (CVU416286) and from (PAPIIT: IN 206617).

\section{Author contribution statement}

G Canul-Medina and C Fernandez-Mejia designed the research, G CanulMedina, L Riverón-Negrete, K Pastén-Hidalgo, $\mathrm{P}$ Morales-Castillo and $\mathrm{F}$ García-Vázquez performed the research, G Canul-Medina, L RiverónNegrete, K Pastén-Hidalgo, and P Morales-Castillo analyzed the data, C Fernandez-Mejia conceived and directed the study as well as provided grant resources and wrote the paper.

\section{Acknowledgements}

The authors are grateful to B S Brianda López-Aviña, B S Lilian EsparzaRosales, B S Armando Elizalde-Gualito from the Unidad de Genética de la Nutrición; to Dr Miguel Tapia Rodríguez from the Unidad de Microscopía and Dr Daniel Garzón Cortés and M V Z Rubí Zavala Gaytán from the Unidad de Modelos Biológicos, Instituto de Investigaciones Biomédicas, Universidad Nacional Autónoma de México, for their technical assistance. The author would wish to thank PhD Candidate Alain de Jesús HernándezVázquez and M S Aarón Rodríguez-Caballero for critical reading of the manuscript.

\section{References}

Ardeshirpour L, Dann P, Adams DJ, Nelson T, Vanhouten J, Horowitz MC \& Wysolmerski JJ 2007 Weaning triggers a decrease in receptor activator of nuclear factor-кB ligand expression, widespread osteoclast apoptosis, and rapid recovery of bone mass after lactation in mice. Endocrinology 148 3875-3886. (https://doi.org/10.1210/en.20061467)
Baaziz N \& Curry DL 1993 Synthesis-secretion coupling of insulin: effect of pregnancy and lactation. Pancreas 8 316-324. (https://doi. org/10.1097/00006676-199305000-00006)

Baeyens L, Hindi S, Sorenson RL \& German MS $2016 \beta$-Cell adaptation in pregnancy. Diabetes, Obesity and Metabolism 18 (Supplement 1) 63-70. (https://doi.org/10.1111/dom.12716)

Beamish CA, Zhang L, Szlapinski SK, Strutt BJ \& Hill DJ 2017 An increase in immature $\beta$-cells lacking Glut 2 precedes the expansion of $\beta$-cell mass in the pregnant mouse. PLOS ONE 12 e0182256. (https://doi. org/10.1371/journal.pone.0182256)

Bell AW \& Bauman DE 1997 Adaptations of glucose metabolism during pregnancy and lactation. Journal of Mammary Gland Biology and Neoplasia 2 265-278. (https://doi.org/10.1023/A:1026336505343)

Brelje TC, Scharp DW, Lacy PE, Ogren L, Talamantes F, Robertson M, Friesen HG \& Sorenson RL 1993 Effect of homologous placental lactogens, prolactins, and growth hormones on islet B-cell division and insulin secretion in rat, mouse, and human islets: implication for placental lactogen regulation of islet function during pregnancy. Endocrinology 132 879-887. (https://doi.org/10.1210/ endo.132.2.8425500)

Burnol AF, Leturque A, Ferre P, Kande J \& Girard J 1986 Increased insulin sensitivity and responsiveness during lactation in rats. American Journal of Physiology 251 E537-E541. (https://doi.org/10.1152/ ajpendo.1986.251.5.E537)

Burnol AF, Ferre P, Leturque A \& Girard J 1987 Effect of insulin on in vivo glucose utilization in individual tissues of anesthetized lactating rats. American Journal of Physiology 252 E183-E188. (https://doi. org/10.1152/ajpendo.1987.252.2.E183)

Canul-Medina G \& Fernandez-Mejia C 2019 Morphological, hormonal, and molecular changes in different maternal tissues during lactation and post-lactation. Journal of Physiological Sciences 69 825-835. (https://doi.org/10.1007/s12576-019-00714-4)

Carrara MA, Batista MR, Saruhashi TR, Felisberto-Junior AMH, Guilhermetti M \& Bazotte RB 2012 Coexistence of insulin resistance and increased glucose tolerance in pregnant rats: a physiological mechanism for glucose maintenance. Life Sciences 90 831-837. (https://doi.org/10.1016/j.lfs.2012.03.037)

Demirci C, Ernst S, Alvarez-Perez JC, Rosa T, Valle S, Shridhar V, Casinelli GP, Alonso LC, Vasavada RC \& García-Ocana A 2012 Loss of HGF/c-Met signaling in pancreatic $\beta$-cells leads to incomplete maternal $\beta$-cell adaptation and gestational diabetes mellitus. Diabetes 61 1143-1152. (https://doi.org/10.2337/db11-1154)

Dirckx N, Tower RJ, Mercken EM, Vangoitsenhoven R, Moreau-Triby C, Breugelmans T, Nefyodova E, Cardoen R, Mathieu C, Van Der Schueren B, et al. 2018 Vhl deletion in osteoblasts boosts cellular glycolysis and improves global glucose metabolism. Journal of Clinical Investigation 128 1087-1105. (https://doi.org/10.1172/JCI97794)

Dirice E, De Jesus DF, Kahraman S, Basile G, Ng RW, El Ouaamari A, Teo AKK, Bhatt S, Hu J \& Kulkarni RN 2019 Human duct cells contribute to $\beta$ cell compensation in insulin resistance. JCI Insight 4 99576. (https://doi.org/10.1172/jci.insight.99576)

Ferron M, Hinoi E, Karsenty G \& Ducy P 2008 Osteocalcin differentially regulates beta cell and adipocyte gene expression and affects the development of metabolic diseases in wild-type mice. PNAS $\mathbf{1 0 5}$ 5266-5270. (https://doi.org/10.1073/pnas.0711119105)

Ferron M, Wei J, Yoshizawa T, Del Fattore A, DePinho RA, Teti A, Ducy P \& Karsenty G 2010 Insulin signaling in osteoblasts integrates bone remodeling and energy metabolism. Cell 142 296-308. (https://doi. org/10.1016/j.cell.2010.06.003)

Fulzele K, Riddle RC, DiGirolamo DJ, Cao X, Wan C, Chen D, Faugere MC, Aja S, Hussain MA, Brüning JC, et al. 2010 Insulin receptor signaling in osteoblasts regulates postnatal bone acquisition and body composition. Cell 142 309-319. (https://doi.org/10.1016/j. cell.2010.06.002)

Gillespie JR, Bush JR, Bell GI, Aubrey LA, Dupuis H, Ferron M, Kream B, DiMattia G, Patel S, Woodgett JR, et al. 2013 GSK-3 $\beta$ function in bone 
regulates skeletal development, whole-body metabolism, and male life span. Endocrinology 154 3702-3718. (https://doi.org/10.1210/ en.2013-1155)

Hakonen E, Ustinov J, Mathijs I, Palgi J, Bouwens L, Miettinen PJ \& Otonkoski T 2011 Epidermal growth factor (EGF)-receptor signalling is needed for murine beta cell mass expansion in response to high-fat diet and pregnancy but not after pancreatic duct ligation. Diabetologia 54 1735-1743. (https://doi.org/10.1007/s00125-0112153-1)

Hills CE, Younis MYG, Bennett J, Siamantouras E, Liu KK \& Squires PE 2012 Calcium-sensing receptor activation increases cell-cell adhesion and $\beta$-cell function. Cellular Physiology and Biochemistry 30 575-586. (https://doi.org/10.1159/000341439)

Huang C, Snider F \& Cross JC 2009 Prolactin receptor is required for normal glucose homeostasis and modulation of beta-cell mass during pregnancy. Endocrinology 150 1618-1626. (https://doi.org/10.1210/ en.2008-1003)

Hudish LI, Reusch JEB \& Sussel L $2019 \beta$ Cell dysfunction during progression of metabolic syndrome to type 2 diabetes. Journal of Clinical Investigation 129 4001-4008. (https://doi.org/10.1172/ JCI129188)

International Diabetes Federation 2019 IDF Diabetes Atlas, 9th ed. Brussels, Belgium. (available at: https://www.diabetesatlas.org).

Jacovetti C, Abderrahmani A, Parnaud G, Jonas JC, Peyot ML, Cornu M, Laybutt R, Meugnier E, Rome S, Thorens B, et al. 2012 MicroRNAs contribute to compensatory $\beta$ cell expansion during pregnancy and obesity. Journal of Clinical Investigation 122 3541-3551. (https://doi. org/10.1172/JCI64151)

Jena MK, Jaswal S, Kumar S \& Mohanty AK 2019 Molecular mechanism of mammary gland involution: an update. Developmental Biology $\mathbf{4 4 5}$ 145-155. (https://doi.org/10.1016/j.ydbio.2018.11.002)

Karsenty G 2017 Update on the biology of osteocalcin. Endocrine Practice 23 1270-1274. (https://doi.org/10.4158/EP171966.RA)

Kim H, Toyofuku Y, Lynn FC, Chak E, Uchida T, Mizukami H, Fujitani Y, Kawamori R, Miyatsuka T, Kosaka Y, et al. 2010 Serotonin regulates pancreatic beta cell mass during pregnancy. Nature Medicine $\mathbf{1 6}$ 804-808. (https://doi.org/10.1038/nm.2173)

Kirby BJ, Ardeshirpour L, Woodrow JP, Wysolmerski JJ, Sims NA, Karaplis AC \& Kovacs CS 2011 Skeletal recovery after weaning does not require PTHrP. Journal of Bone and Mineral Research 26 1242-1251. (https://doi.org/10.1002/jbmr.339)

Kovacs CS 2011 Calcium and bone metabolism disorders during pregnancy and lactation. Endocrinology and Metabolism Clinics of North America 40 795-826. (https://doi.org/10.1016/j.ecl.2011.08.002)

Kovacs CS 2016 Maternal mineral and bone metabolism during pregnancy, lactation, and post-weaning recovery. Physiological Reviews 96 449-547. (https://doi.org/10.1152/physrev.00027.2015)

Lacombe J, Karsenty G \& Ferron M 2013 In vivo analysis of the contribution of bone resorption to the control of glucose metabolism in mice. Molecular Metabolism 2 498-504. (https://doi.org/10.1016/j. molmet.2013.08.004)

Lazo de la Vega ML, Larrieta E, German MS, Baez-Saldana A \& FernandezMejia C 2013 Effects of biotin supplementation in the diet on insulin secretion, islet gene expression, glucose homeostasis and beta-cell proportion. Journal of Nutritional Biochemistry 24 169-177. (https:// doi.org/10.1016/j.jnutbio.2012.03.020)

Lee AV, Zhang P, Ivanova M, Bonnette S, Oesterreich S, Rosen JM, Grimm S, Hovey RC, Vonderhaar BK, Kahn CR, et al. 2003 Developmental and hormonal signals dramatically alter the localization and abundance of insulin receptor substrate proteins in the mammary gland. Endocrinology 144 2683-2694. (https://doi. org/10.1210/en.2002-221103)

Lee NK, Sowa H, Hinoi E, Ferron M, Ahn JD, Confavreux C, Dacquin R, Mee PJ, McKee MD, Jung DY, et al. 2007 Endocrine regulation of energy metabolism by the skeleton. Cell 130 456-469. (https://doi. org/10.1016/j.cell.2007.05.047)
Marynissen G, Aerts L \& Van Assche FA 1983 The endocrine pancreas during pregnancy and lactation in the rat. Journal of Developmental Physiology 5 373-381.

Marynissen G, Malaisse WJ \& Van Assche FA 1985 Ultrastructural changes of the pancreatic $\beta$-cell and the insulin secretion by islets from lactating and non-lactating rats. Journal of Developmental Physiology 7 $17-23$.

Meier JJ \& Bonadonna RC 2013 Role of reduced $\beta$-cell mass versus impaired $\beta$-cell function in the pathogenesis of type 2 diabetes. Diabetes Care 36 (Supplement 2) S113-S119. (https://doi.org/10.2337/ dcS13-2008)

Miller SC, Anderson BL \& Bowman BM 2005 Weaning initiates a rapid and powerful anabolic phase in the rat maternal skeleton. Biology of Reproduction 73 156-162. (https://doi.org/10.1095/ biolreprod.105.039610)

Montanya E \& Téllez N 2009 Pancreatic remodeling: beta-cell apoptosis, proliferation and neogenesis, and the measurement of beta-cell mass and of individual beta-cell size. Methods in Molecular Biology 560 137-158. (https://doi.org/10.1007/978-1-59745-448-3_11)

Neville MC, McFadden TB \& Forsyth I 2002 Hormonal regulation of mammary differentiation and milk secretion. Journal of Mammary Gland Biology and Neoplasia 7 49-66. (https://doi. org/10.1023/a:1015770423167)

Nielsen JH 2016 Beta cell adaptation in pregnancy: a tribute to Claes Hellerström. Upsala Journal of Medical Sciences 121 151-154. (https:// doi.org/10.3109/03009734.2016.1165776)

Ohara M, Kim H, Yoshida M, Fujiwara T, Aoyagi K, Toyofuku Y, Nakamichi Y, Nishiwaki C, Okamura T, Uchida T, et al. 2013 Serotonin regulates glucose-stimulated insulin secretion from pancreatic cells during pregnancy. PNAS 110 19420-19425. (https://doi.org/10.1073/ pnas.1310953110)

Oldknow KJ, MacRae VE \& Farquharson C 2015 Endocrine role of bone: recent and emerging perspectives beyond osteocalcin. Journal of Endocrinology 225 R1-R19. (https://doi.org/10.1530/JOE-14-0584)

Palou A, Remesar X, Arola L \& Alemany M 1982 Changes induced in rat plasma composition by lactation. Archives Internationales de Physiologie et de Biochimie 90 185-190. (https://doi. org/10.3109/13813458209070570)

Parsons JA, Brelje TC \& Sorenson RL 1992 Adaptation of islets of Langerhans to pregnancy: increased islet cell proliferation and insulin secretion correlates with the onset of placental lactogen secretion. Endocrinology 130 1459-1466. (https://doi.org/10.1210/ endo.130.3.1537300)

Quesada C, Tudurí E, Marroquí L, Alonso P, Quesada I \& Nadal Á 2020 Morphological and functional adaptations of pancreatic alpha-cells during late pregnancy in the mouse. Metabolism 69 825-835. (https:// doi.org/10.1016/j.metabol.2019.153963)

Rieck S \& Kaestner KH 2010 Expansion of beta-cell mass in response to pregnancy. Trends in Endocrinology and Metabolism 21 151-158. (https://doi.org/10.1016/j.tem.2009.11.001)

Scaglia L, Smith FE \& Bonner-Weir S 1995 Apoptosis contributes to the involution of beta cell mass in the post partum rat pancreas. Endocrinology 136 5461-5468. (https://doi.org/10.1210/ endo.136.12.7588296)

Sorenson RL \& Brelje TC 1997 Adaptation of islets of Langerhans to pregnancy: $\beta$-cell growth, enhanced insulin secretion and the role of lactogenic hormones. Hormone and Metabolic Research 29 301-307. (https://doi.org/10.1055/s-2007-979040)

Squires PE, Jones PM, Younis MYG \& Hills CE 2014 The calcium-sensing receptor and $\beta$-cell function. In The Pancreatic Beta Cell, pp. 249-267. Eds GBT-V \& H Litwack. Academic Press. (https://doi.org/10.1016/ B978-0-12-800174-5.00010-7)

Sullivan TR, Duque G, Keech AC \& Herrmann M 2013 An old friend in a new light: the role of osteocalcin in energy metabolism. Cardiovascular Therapeutics 31 65-75. (https://doi.org/10.1111/j.17555922.2011.00300.x) https://joe.bioscientifica.com

https://doi.org/10.1530/JOE-20-0184 (c) 2021 Society for Endocrinology Published by Bioscientifica Ltd. Printed in Great Britain 
Takeno A, Kanazawa I, Notsu M, Tanaka KI \& Sugimoto T 2018 Glucose uptake inhibition decreases expressions of receptor activator of nuclear factor-kappa B ligand (RANKL) and osteocalcin in osteocytic MLO-Y4-A2 cells. American Journal of Physiology: Endocrinology and Metabolism 314 E115-E123. (https://doi.org/10.1152/ ajpendo.00159.2017)

Teixeira CJ, Santos-Silva JC, de Souza DN, Rafacho A, Anhe GF \& Bordin S 2019 Dexamethasone during pregnancy impairs maternal pancreatic $\beta$-cell renewal during lactation. Endocrine Connections 8 120-131. (https://doi.org/10.1530/EC-18-0505)

Toselli C, Hyslop CM, Hughes M, Natale DR, Santamaria P \& Huang CTL 2014 Contribution of a non- $\beta$-cell source to $\beta$-cell mass during pregnancy. PLOS ONE 9 e100398. (https://doi.org/10.1371/journal. pone.0100398)

Vasu S, Moffett RC, Thorens B \& Flatt PR 2014 Role of endogenous GLP-1 and GIP in beta cell compensatory responses to insulin resistance and cellular stress. PLOS ONE 9 e101005. (https://doi.org/10.1371/journal. pone.0101005)

Wei J, Shimazu J, Makinistoglu MP, Maurizi A, Kajimura D, Zong H, Takarada T, Lezaki T, Pessin JE, Hinoi E, et al. 2015 Glucose uptake and Runx2 synergize to orchestrate osteoblast differentiation and bone formation. Cell 161 1576-1591. (https://doi.org/10.1016/j. cell.2015.05.029)
Weir GC, Laybutt DR, Kaneto H, Bonner-Weir S \& Sharma A 2001 -Cell adaptation and decompensation during the progression of diabetes. Diabetes 50 (Supplement 1) S154-S159. (https://doi.org/10.2337/ diabetes.50.2007.s154)

Williamson DH 1980 Integration of metabolism in tissues of the lactating rat. FEBS Letters 117 (Supplement) K93-K105. (https://doi. org/10.1016/0014-5793(80)80574-6)

$\mathrm{Xu} \mathrm{H}$, Abuhatzira L, Carmona GN, Vadrevu S, Satin LS \& Notkins AL 2015 The Ia- $2 \beta$ intronic miRNA, miR-153, is a negative regulator of insulin and dopamine secretion through its effect on the Cacna1c gene in mice. Diabetologia 58 2298-2306. (https://doi.org/10.1007/ s00125-015-3683-8)

Yao Q, Yu C, Zhang X, Zhang K, Guo J \& Song L 2017 Wnt/ $\beta$-catenin signaling in osteoblasts regulates global energy metabolism. Bone $\mathbf{9 7}$ 175-183. (https://doi.org/10.1016/j.bone.2017.01.028)

Yoshikawa Y, Kode A, Xu L, Mosialou I, Silva BC, Ferron M, Clemens TL, Economides AN \& Kousteni S 2011 Genetic evidence points to an osteocalcin-independent influence of osteoblasts on energy metabolism. Journal of Bone and Mineral Research 26 2012-2025 (https://doi.org/10.1002/jbmr.417)

Zoch ML, Clemens TL \& Riddle RC 2016 New insights into the biology of osteocalcin. Bone 82 42-49. (https://doi.org/10.1016/j. bone.2015.05.046)

Received in final form 7 October 2020

Accepted 13 October 2020

Accepted Manuscript published online 13 October 2020
(C) 2021 Society for Endocrinology Published by Bioscientifica Ltd.
Printed in Great Britain 